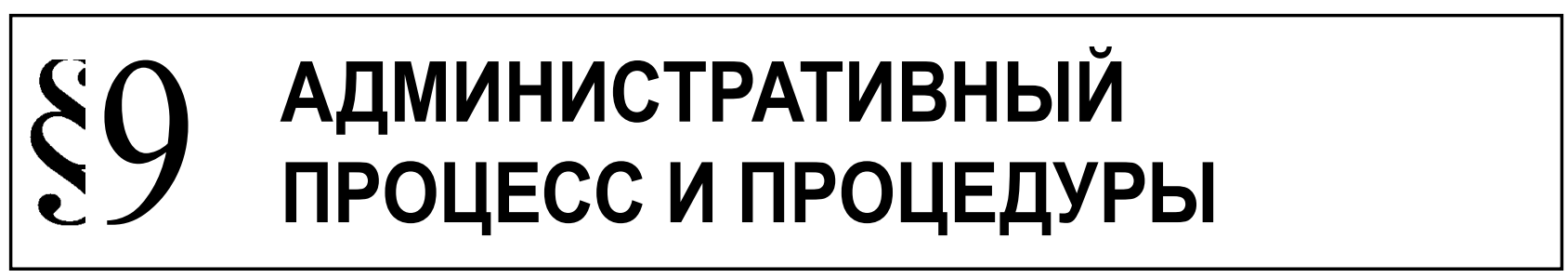

Константинова Л.В.

\title{
ЗАКОНОДАТЕЛЬСТВО ОБ АДМИНИСТРАТИВНЫХ ПРАВОНАРУШЕНИЯХ ГОСУДАРСТВ - ЧЛЕНОВ ТАМОЖЕННОГО СОЮЗА В ЧАСТИ ПРОИЗВОДСТВА ПО ДЕЛАМ ОБ АДМИНИСТРАТИВНЫХ ПРАВОНАРУШЕНИЯХ, ОТНЕСЕННЫХ К КОМПЕТЕНЦИИ ТАМОЖЕННЫХ ОРГАНОВ
}

Аннотация: Статья посвящена анализу современного состояния общественных отношений в рамках производства по делам об административных правонарушениях, отнесенных к компетенции таможенных органов, в условиях функционирования Таможенного союза, административного законодательства государств - членов Таможенного союза, выявлению особенностей, присущих национальному законодательству той или иной страны, а также несоответствий, препятствующих эффективному ведению производства по делам об административных правонарушениях в условиях функционирования Таможенного союза, выработке предложений посовершенствованию законодательства государств - членов Таможенного союза в области производства по делам об административных правонарушениях В целях выработки предложений по совершенствованию законодательства в области производства по делам об административных правонарушениях, применены научный и сравнительный методы исследования Проведенный анализ в целом показал наличие в трех странах общих принципов и подходов, применяемых таможенными органами при привлечении лиц к административной ответственности. Вместе с тем выявлен и ряд особенностей, присущих национальному законодательству той или иной страны, а также несоответствий, препятствующих эффективному ведению производства по делам об административных правонарушениях в условиях функционирования Таможенного союза.Выводы:В целях эфрективного ведения производства по делам об административных правонарушениях в условиях функционирования Таможенного союза необходимо привести к единообразию нормы законодательства об административной ответственности государств - членов Таможенного союза, то есть к унификации, в части:1. Ввести в КоАП РФ и КоАП РК институт соучастия, когда к ответственности наряду с исполнителем привлекаются организатор и пособник правонарушения, как это прямо предусмотрено в КоАП РБ.2. Ввести в КоАП РФ и КоАП РК институт покушения на совершение АП в случаях, как это прямо предусмотрено в КоАП РБ. З. Установить едиными сроки давности привлечения к административной ответственности за нарушение таможенных правил в кодексах об административной ответственности государств - членов Таможенного союза.4. Ввести институт приостановления течения срока давности привлечения к административной ответственности, как это прямо предусмотрено в КоАП РК.5. Ввести институт соединения в КоАП РФ, как это прямо предусмотрено в КоАП РК и КоАП РБ).

Ключевые слова: административное правонарушение, национальное законодательство, таможенные органы, Российская Федерация, Республика Казахстан, Республика Беларусь, Таможенный союз, дифференциация наказания, конфискация, соучастие.

6 июля 2010 года действует Таможенный кодекс Таможенного союза ${ }^{1}$ (далее - ТК ТС), в соответствии с которым в Российской Федерации, Республике Беларусь и Республике
Казахстан таможенное регулирование осуществляется по единым правилам, определенным таможенным законодательством Таможенного союза. 
При этом согласно части 3 статьи 7 ТК ТС вопросы привлечения лиц к административной ответственности за нарушения таможенных правил, а также ведения административного процесса (осуществления производства) по делам об административных правонарушениях (далее - АП) регулируются на уровне национального законодательства государств - членов Таможенного союза.

В государствах - членах Таможенного союза соответствующие правоотношения регламентированы следующими национальными кодифицированными актами: Кодекс Российской Федерации ${ }^{2}$ (далее - КоАП РФ), Кодекс об административных правонарушениях Республики Казахстан ${ }^{3}$ (далее - КоАП РК) и Кодекс об административных правонарушениях Республики Беларусь (далее - КоАП РБ) ${ }^{4}$, Процессуально-исполнительным кодексом об административных правонарушениях Республики Беларусь (далее - ПИКоАП РБ)

КоАП РФ и КоАП РК имеют аналогичную структуру, состоящую из общих положений, определяющих задачи и принципы законодательства об административных правонарушениях, вопросы административной ответственности и наказания, а также особенной части, положений о порядке производства по делам об АП и исполнения постановлений по делам об АП.

В отличие от КоАП РФ и КоАП РК в Республике Беларусь вопросы процессуального характера регламентированы отдельным законодательным актом -ПиКоАП РБ.

Правонарушения в области таможенного дела в Кодексах государств - членов Таможенного союза регламентированы нормами отдельных глав:

- глава 16 КоАП РФ «Административные правонарушения в области таможенного дела (нарушение таможенных правил)» состоит из 24 статей; 1. Кодекс об административных правонарушениях Республики Казахстан: Закон Республики Казахстан от 30.01.2001 № 156-II [Электронный ресурс]. URL:http://www.zakon.kz/static/administrativnyykodex. $\mathrm{html}$ / (дата обращения: 24.02.2014).

2. Процессуально - исполнительный кодекс Республики Беларусь: Закон Республики Беларусь от 20.12.2006 № 194-3 [Электронный ресурс]. URL: http://tamby.info/kodeks/pikoap.htm / (дата обращения: 24.02.2014).

3. Кодекс об административных правонарушениях Республики Беларусь: Закон Республики Беларусь от 21.04.2003 № 194-3 [Электронный реcypc]. URL: http://tamby.info/kodeks/pikoap.htm / (дата обращения: 24.02.2014).
4. Кодекс Российской Федерации об административныхправонарушениях. (в ред. от 15.02.2014 № 6-Ф3) // Собрание законодательства РФ.2002, № 1 (ч. 1). Ст. 1.

5. Таможенный кодекс Таможенного союза (приложение к Договору о Таможенном кодексе Таможенного союза, принятому Решением Межгосударственного совета ЕврАзЭС на уровне глав государств от 27.11.2009 № 17) (в ред. от 16.04.2010) // Собрание законодательства РФ.2010. № 50. Ст. 6615.

- глава 14 КоАП РБ «Административные правонарушения против порядка таможенного регулирования (административные таможенные правонарушения)» - 19 статей;

- глава 26 КоАП РК «Административные правонарушения в сфере таможенного дела» - 40 статей.

В соответствии с национальным законодательством государств - членов Таможенного союза таможенные органы не только возбуждают дела об АП в области таможенного дела, но и наделены полномочиями по их рассмотрению.

Таможенные органы также вправе возбуждать дела об АП, не относящиеся к таможенным правонарушениям. Например, в области предпринимательской деятельности, эксплуатации транспорта (Республика Казахстан, Республика Беларусь, Российская Федерация), общественной

безопасности и здоровья населения (Республика Казахстан, Российская Федерация), финансов и банковской деятельности (Республика Беларусь, Российская Федерация), охраны собственности (Российская Федерация), нарушения прав и свобод человека и гражданина (Республика Беларусь).

В отличие от Российской Федерации таможенные органы Республики Беларусь и Республики Казахстан наделены, в том числе, правом рассматривать некоторые дела об АП, относящиеся к сфере финансов, банковской деятельности, промышленности, охраны окружающей среды, общественной безопасности и здоровья населения, эксплуатации транспорта.

В целях обеспечения соблюдения таможенного законодательства Таможенного союза и государств - членов Таможенного союза, а также, принимая во внимание, что в каждой из трех стран действует свое национальное административное законодательство, Решением Межгоссовета ЕврАзЭС от 5 июля 2010 года № 50 принят Договор об особенностях уголовной и административной ответственности за нарушения таможенного зако- 
нодательства Таможенного союза и государств членов Таможенного союза ${ }^{7}$ (далее - Договор), которым установлены единые правила и механизмы привлечения лиц к ответственности за нарушения таможенного законодательства Таможенного союза.

Одним из основополагающих принципов, предусмотренных Договором, является принцип возбуждения дела об АП по месту его выявления, а не по месту совершения, что позволяет таможенным органам государства - члена Таможенного союза своевременно привлекать лиц к административной ответственности на основании своего национального законодательства даже в том случае, если оно совершено на территории другого государства - члена Таможенного союза.

Однако для применения данного порядка потребовалось приведение в соответствие с Договором и национального законодательства об административных правонарушениях в части действия его в пространстве. Так, частью 2 статьи 1.8 КоАП РФ предусмотрено, что лицо, совершившее АП за пределами Российской Федерации, подлежит административной ответственности в соответствии с Кодексом в случаях, предусмотренных международным договором Российской Федерации. Наличие указанной нормы с учетом положений Договора позволяет таможенным органам Российской Федерации, например, при завершении таможенной процедуры таможенного транзита привлекать перевозчика к административной ответственности за повреждение средств идентификации, в том числе в тех случаях, когда повреждение произошло на территории Республики Казахстан либо Республики Беларусь.

В отличие от российского законодательства законодательством Республики Казахстан ответственность в случаях совершения правонарушения за пределами государства не предусмотрена. При указанных обстоятельствах таможенные органы Республики Казахстан не смогут привлечь участников внешнеэкономической деятельности к административной ответственности за нарушения таможенного законодательства Таможенного союза, совершенные на территории Российской Федерации или Республики Беларусь.

В Республике Беларусь оговорены конкретные условия, при которых за правонарушения, совершенные вне пределов страны, наступает ответственность в соответствии с национальным законодательством, а именно: если субъектами административной ответственности являются граждане Республики Беларусь или лица без гражданства, постоянно проживающие на территории Республики Беларусь, и если совершенные ими деяния наказуемы в государстве, на территории которого они были совершены, и если эти лица не были там привлечены к ответственности. В указанных случаях административное взыскание (наказание) налагается на лицо в пределах санкции соответствующей статьи, но не должно превышать верхний предел санкции, предусмотренной законом государства, на территории которого совершено правонарушение.

Вместе с тем нормами национального законодательства Республики Беларусь (статья 33 Закона Республики Беларусь от 23.07.2008 № 421-3 «0 международных договорах Республики Беларусь», статья 20 Закона Республики Беларусь от 10.01.2001 № 361-3 «0 нормативных правовых актах Республики Беларусь») предусмотрено непосредственное применение норм права, содержащихся в международных договорах Республики Беларусь, ввиду чего при принятии решения о возбуждении дела об административном правонарушении, таможенные органы Республики Беларусь руководствуются положениями, изложенными в статье 4 Договора.

Другим основополагающим критерием, исходя из которого применяются нормы административного законодательства, является его действие во времени. Общим принципом для государств членов Таможенного союза является применение к лицу, совершившему противоправное деяние, закона, действовавшего во время его совершения. Также нормами Кодексов трех стран предусмотрено, что закон, смягчающий или отменяющий ответственность за АП (в КоАП России и КоАП Республики Беларусь - в том числе иным образом улучшающий положение лица), имеет обратную силу, то есть распространяется на лицо, которое совершило правонарушение до вступления соответствующего закона в силу.

В качестве субъектов административной ответственности в государствах - членах Таможенного союза выступают физические (в том числе должностные лица, индивидуальные предприниматели) и юридические лица.

Во всех Кодексах предусмотрена дифференциация наказания в зависимости от категории субъекта ответственности: физическое лицо, должностное лицо, индивидуальный предприниматель, юридическое лицо. При этом в отличие от КоАП РК и КоАП РБ, в которых индивидуальные предпри- 
ниматели по некоторым составам АП в области таможенного дела выделены в качестве самостоятельного субъекта (например, при незаконном перемещении товаров через таможенную границу Таможенного союза), в Российской Федерации индивидуальные предприниматели несут административную ответственность как юридические лица, то есть к ним применяются те же санкции, которые предусмотрены для юридических лиц.

Кроме того, нормами КоАП РК предусмотрена дифференциация наказания юридических лиц в зависимости от отнесения их к субъектам малого или среднего предпринимательства, крупного предпринимательства.

Отличительной особенностью КоАП РБ является наличие институтов соучастия, когда к ответственности наряду с исполнителем привлекаются организатор и пособник правонарушения, а также покушения на совершение АП в случаях, прямо предусмотренных КоАП РБ.

За нарушения законодательства об АП, возбуждение дел по которым отнесено к компетенции таможенных органов, в государствах - членах Таможенного союза применяются такие основные виды административного наказания (взыскания) как предупреждение, штраф и конфискация. При этом предупреждение и штраф могут налагаться непосредственно таможенными органами. Решение о конфискации принимается только судами.

В Республике Беларусь наказание в виде конфискации применяется только к собственникам товаров, явившихся предметом АП, за исключением случаев, когда санкциями отдельных правонарушений предусмотрено применение конфискации в отношении предмета АП независимо от того, в чьей собственности он находится (например, за сокрытие товаров от таможенного контроля).

Административным законодательством каждого государства за отдельные административные правонарушения (как в области таможенного дела, так и в других областях), отнесенные к компетенции таможенных органов, предусмотрены также иные виды административного наказания (взыскания). В Республике Казахстан - это исключение из соответствующего реестра лиц, осуществляющих деятельность в сфере таможенного дела (по решению таможенного органа), приостановление деятельности лицензии на определенный вид деятельности, лишение права управления транспортным средством на срок один год (только по решению суда). В Российской Федерации - дисквалификация и административное приостановление деятельности (только по решению суда). В Республике Беларусь - лишение права заниматься определенной деятельностью и взыскание стоимости предмета АП (принудительное обращение в собственность государства денежной суммы, составляющей стоимость предмета АП), которые применяются только по решению суда.

Административным законодательством государств - членов Таможенного союза предусмотрен общий принцип, согласно которому наложение административного наказания (взыскания) не освобождает лицо от исполнения обязанности, за неисполнение которой оно было назначено.

При назначении административного наказания (взыскания) в государствах - членах Таможенного союза в обязательном порядке учитываются отягчающие и смягчающие обстоятельства, которые в целом не отличаются друг от друга, за некоторыми исключениями (например, в качестве смягчающего обстоятельства в Республике Беларусь признается совершение АП лицом, достигшим семидесяти лет).

Срок, по истечении которого лицо считается не подвергавшимся административному наказанию (взысканию) является одинаковым в трех государствах и составляет один год со дня окончания исполнения соответствующего решения.

Сроки давности привлечения к административной ответственности за нарушение таможенных правил в государствах - членах Таможенного союза являются различными. Так, в Республике Казахстан они составляют два месяца со дня совершения (при длящемся - дня обнаружения) АП, в Российской Федерации - 2 года со дня совершения (при длящемся - дня обнаружения) АП, в Республике Беларусь - 3 года со дня его совершения и 6 месяцев со дня его обнаружения.

При этом в Республике Казахстан, в отличие от Российской Федерации и Республики Беларусь, действует институт приостановления течения срока давности привлечения к административной ответственности. Указанные сроки приостанавливаются с момента направления дела в судебные инстанции или должностному лицу государственного органа, уполномоченного рассматривать дела об АП. Исчисление сроков возобновляется в случаях возвращения дела органу, уполномоченному возбуждать дела об АП, для устранения недостатков.

Анализ составов правонарушений в области таможенного дела трех государств показал, что КоАП РФ и КоАП РК приведены в соответствие с таможенным законодательством Таможенного союза. 
Большая часть составов правонарушений в области таможенного дела, предусмотренных национальными законодательствами государств - членов Таможенного союза, охватывает деяния, которые связаны с несоблюдением установленного нормами ТК ТС порядка таможенного регулирования.

Так, административным законодательством трех стран противоправными признаются, деяния, связанные с нарушением установленного порядка перемещения товаров через таможенную границу Таможенного союза; с сокрытием товаров от таможенного контроля; с сообщением недостоверных сведений о товарах (представлением недействительных документов) при перемещении товаров через таможенную границу Таможенного союза; с недекларированием либо недостоверным декларированием; с несоблюдением установленных запретов и ограничений; с нарушением режима зоны таможенного контроля; с недоставкой товаров в определенное таможенным органом место доставки при перемещении товаров в соответствии с таможенной процедурой таможенного транзита.

Примером являются составы АП, связанные с недекларированием и недостоверным декларированием товаров. Если в Республике Беларусь и Республике Казахстан эти два деяния образуют один состав, за который установлен фиксированный штраф, то в Российской Федерации они являются самостоятельными и за каждое из них установлено отдельное наказание: за недекларирование - административный штраф, кратный стоимости товаров, являющихся предметом АП, за недостоверное декларирование - административный штраф, кратный сумме неуплаченных таможенных пошлин, налогов. Некоторые деяния, ответственность за которые предусмотрена законодательством одного из государств - членов Таможенного союза, не признаются противоправными в соответствии с законодательством другого государства - члена Таможенного союза. В Российской Федерации, например, административная ответственность предусмотрена за незавершение в установленные сроки таможенной процедуры, в Республике Беларусь - за невывоз товаров, в отношение которых выдано разрешение на убытие, в Республике Казахстан - за неостановку транспортного средства, следующего через таможенную границу Таможенного союза; за нарушение порядка перемещения товаров в международных почтовых отправлениях; за неисполнение банком, страховой организацией, поручителем требования об уплате таможенных платежей.
В отличие от Республики Казахстан в Российской Федерации и Республике Беларусь противоправным признается деяние, выразившееся в использовании временно ввезенных транспортных средств международной перевозки во внутренних перевозках. При этом, если согласно КоАП РФ незаконным признается использование таких транспортных средств во внутренних перевозках на всей таможенной территории Таможенного союза, то в Республике Беларусь ответственность наступает только при выявлении факта такого использования во внутриреспубликанских перевозках.

Вместе с тем планируемые изменения в КоАП РБ устранят имеющиеся расхождения с положениями таможенного законодательства Таможенного союза.

В соответствии с национальным законодательством Республики Беларусь и Республики Казахстан противоправным признается деяние, выразившееся в неуведомлении таможенного органа о прибытии товаров на таможенную территорию данных государств. В Российской Федерации за указанное деяние административная ответственность не предусмотрена.

В ходе подготовки обзора проведен анализ размеров штрафных санкций (в рублевом эквиваленте), налагаемых за одни и те же АП в области таможенного дела в государствах - членах Таможенного союза.

В результате выявлено наличие в трех странах различного подхода к дифференциации применяемого наказания в зависимости от субъекта ответственности, а также разница в величине налагаемых штрафов.

Примеры административных штрафов за отдельные правонарушения приведены в таблице.

Указанные в таблице данные свидетельствуют, что в Российской Федерации за каждое из рассматриваемых АП штраф налагается, в зависимости от субъекта правонарушения, в то время как в Республике Казахстан и Республике Беларусь дифференциация штрафа по такому критерию в ряде случаев отсутствует. Кроме того, за все приведенные составы правонарушений в Российской Федерации размеры штрафных санкций, налагаемых на юридических лиц, превышают размеры штрафов, применяемых в Республике Казахстан и Республике Беларусь.

В целях всестороннего, полного, объективного и своевременного выяснения обстоятельств дела об АП таможенные органы Республики Беларусь, Российской Федерации и Республики Казахстан на- 
Административное и муниципальное право 11 (83) • 2014

\begin{tabular}{|c|c|c|}
\hline Российская Федерация & Республика Казахстан & Республика Беларусь \\
\hline \multicolumn{3}{|c|}{ Нарушение режима зоны таможенного контроля } \\
\hline $\begin{array}{l}\text { - граждане - от } 300 \text { до } 500 \text { рублей; } \\
\text { - должностные лица - от } 500 \text { до } \\
1000 \text { рублей; } \\
\text { - юридические лица - от } 5000 \text { до } \\
10000 \text { рублей. }\end{array}$ & $\begin{array}{l}\text { - физические лица, должностные лица, индивидуальные } \\
\text { предприниматели - от } 1650 \text { до } 3300 \text { российских рублей; } \\
\text { - юридические лица, являющихся субъектами малого } \\
\text { или среднего предпринимательства, - от } 3300 \text { до } 4950 \\
\text { российских рублей; } \\
\text { - юридические лица, являющихся субъектами крупного } \\
\text { предпринимательства, - от } 6600 \text { до } 8250 \text { российских } \\
\text { рублей. }\end{array}$ & $\begin{array}{l}\text { вне зависимости от субъекта } \\
\text { ответственности - от } 720 \text { до } \\
3600 \text { российских рублей. }\end{array}$ \\
\hline \multicolumn{3}{|c|}{$\begin{array}{c}\text { Недоставка товаров в определенное таможенным органом место доставки при перемещении товаров } \\
\text { в соответствии с таможенной процедурой таможенного транзита }\end{array}$} \\
\hline $\begin{array}{l}\text { - граждане - от } 1500 \text { до } 2500 \\
\text { рублей; } \\
\text { - должностные лица - от } 10000 \text { до } \\
20000 \text { тысяч рублей; } \\
\text { - юридические лица - от } 300000 \\
\text { до } 500000 \text { рублей. }\end{array}$ & $\begin{array}{l}\text { вне зависимости от субъекта ответственности - } \\
13200 \text { российских рублей. }\end{array}$ & $\begin{array}{l}\text { - физические лица - от } 1800 \\
\text { до } 10800 \text { российских рублей; } \\
\text { - индивидуальные предпри- } \\
\text { ниматели - от } 3600 \text { до } 36000 \\
\text { российских рублей; } \\
\text { - юридические лица - от } 7200 \\
\text { до } 180000 \text { российских рублей. }\end{array}$ \\
\hline \multicolumn{3}{|c|}{ Уничтожение, удаление, изменение либо утрата средств идентификации } \\
\hline $\begin{array}{l}\text { - граждане - от } 300 \text { до } 1000 \text { рублей; } \\
\text { - должностные лица - от } 500 \text { до } \\
2000 \text { рублей; } \\
\text { - юридические лица - от } 5000 \text { до } \\
20000 \text { рублей. }\end{array}$ & $\begin{array}{l}\text { вне зависимости от субъекта ответственности - от } 1650 \text { до } \\
3300 \text { российских рублей. }\end{array}$ & $\begin{array}{l}\text { вне зависимости от субъекта } \\
\text { ответственности - от } 720 \text { до } 3 \\
600 \text { российских рублей. }\end{array}$ \\
\hline
\end{tabular}

делены рядом процессуальных полномочий: применение мер обеспечения производства по делу об АП, получение объяснений участников производства по делу, взятие проб, назначение экспертиз, истребование сведений.

В соответствии с КоАП РФ в случаях, когда проведение процессуальных действий связано со значительными временными затратами, по отдельным составам АП проводится административное расследование. Максимальный срок административного расследования для таможенных органов Российской Федерации составляет шесть месяцев. После завершения административного расследования составляется протокол об АП либо выносится постановление о прекращении дела.

В Республике Беларусь действует похожий механизм, который предусматривает возможность осуществления процессуальных мероприятий до вынесения протокола об АП и направления его на рассмотрение - подготовка дела об АП к рассмотрению, общий срок которой составляет по делам об административных таможенных правонарушениях два месяца со дня начала административного процесса. При этом сама подготовка к рассмотрению может быть приостановлена на неопределенный срок, если по делу назначена и проводится экспертиза либо запрошена информация из иностранного государства. По окончании подготовки составляется протокол об АП либо выносится постановление о прекращении дела.
В КоАП Республики Казахстан стадии, схожие с административным расследованием, не предусмотрены, а в случаях, когда требуется проведение экспертиз, протокол об АП составляется в течение суток с момента получения заключения эксперта.

Законодательством государств - членов Таможенного союза предусмотрен упрощенный порядок привлечения виновных лиц к административной ответственности, то есть без составления протокола об АП. При этом в отличие от Российской Федерации, в Республике Беларусь и Республике Казахстан применение упрощенного порядка возможно только при уплате штрафа на месте совершения АП.

Кодексами трех стран установлены обстоятельства, при наличии которых производство по делу (административный процесс) подлежит прекращению. Перечень их в целом одинаковый. Вместе с тем в Республике Беларусь в качестве самостоятельного основания прекращения административного процесса признается также прекращение деятельности индивидуального предпринимателя, признание его экономически несостоятельными (банкротом).

В отличие от Российской Федерации в национальных законодательствах Республики Казахстан и Республики Беларусь предусмотрена возможность освобождения в некоторых случаях лица от административной ответственности при условии устранения нарушений и (или) возмещения при- 
чиненного государству или иным лицам вреда. При этом указанные действия являются в соответствии с Кодексами двух стран также смягчающими обстоятельствами. В Российской Федерации добровольное возмещение виновным лицом причиненного ущерба или добровольное устранение причиненного вреда рассматривается только в качестве обстоятельства, смягчающего административную ответственность.

Административным законодательством государств - членов Таможенного союза обозначен круг участников производства по делу об АП (административном процессе), к числу которых относятся: лицо, в отношении которого ведется административное производство (административный процесс), потерпевший, представитель (законный) юридического лица, защитник, эксперт, специалист, переводчик. Различия в правах и обязанностях участников производства по делу об АП являются незначительными. Например, в отличие от Российской Федерации и Республики Беларусь в КоАП РК установлены случаи обязательного участия защитника при производстве по делу, в случае незнания лицом, привлекаемым к административной ответственности, языка, на котором ведется производство.

Таможенные органы государств - членов Таможенного союза в целях пресечения АП, установления личности нарушителя, составления протокола об АП, обеспечения своевременного и правильного разрешения дела и исполнения принятого по делу постановления вправе применять такие меры обеспечения производства по делу об АП как административное задержание, личный досмотр (обыск), изъятие вещей и документов, привод. В Российской Федерации таможенными органами могут быть также применены: временный запрет деятельности, задержание судна, доставленного в порт Российской Федерации, арест судна, доставленного в порт Российской Федерации, залог за арестованное судно. В Республике Беларусь предусмотрена мера обеспечения в виде наложения ареста на имущество, не являющегося предметом правонарушения, с целью обеспечения исполнения взыскания административного штрафа.

При этом КоАП РК и ПИКоАП РБ предусмотрен порядок обжалования мер обеспечения производства по делам об АП.

После составления протокола об АП по общему правилу, предусмотренному законодательством государств - членов Таможенного союза, он направляется для рассмотрения в суд, орган (долж- ностному лицу), уполномоченным рассматривать дела об АП.

Нормами законодательства государств - членов Таможенного союза установлен одинаковый (пятнадцатидневный) срок рассмотрения дела об АП со дня получения протокола об АП и других материалов дела. При этом если в Республике Казахстан и Республике Беларусь данный срок касается всех категорий субъектов, уполномоченных рассматривать дела об АП, то в Российской Федерации судом дело подлежит рассмотрению в двухмесячный срок со дня получения протокола об АП и других материалов дела.

В Республике Беларусь и Республике Казахстан предусмотрена возможность соединения в одном административном процессе дел об АП в установленных законодательством случаях (когда несколько АП совершены одним лицом, если они подведомственны одному и тому же суду, органу, ведущему административный процесс).

По окончании рассмотрения дела об АП выносится постановление о назначении административного наказания (взыскания) либо о прекращении производства по делу об АП, которые могут быть обжалованы и опротестованы в установленном порядке.

В соответствии с административным законодательством трех стран постановление по делу об АП вступает в законную силу по истечении десяти дней (суток) со дня вручения (объявления) или получения копии постановления ${ }^{6}$.

Проведенный анализ административного законодательства государств - членов Таможенного союза в целом показал наличие в трех странах общих принципов и подходов, применяемых таможенными органами при привлечении лиц к административной ответственности. Вместе с тем выявлен и ряд особенностей, присущих национальному законодательству той или иной страны, а также несоответствий, препятствующих эффективному ведению производства по делам об административных правонарушениях в условиях функционирования Таможенного союза.

\section{Выводы:}

В целях эффективного ведения производства по делам об административных правонарушениях в условиях функционирования Таможенного союза необходимо привести к единообразию нормы законодательства об административной ответственности государств - членов Таможенного союза, то есть к унификации, в части: 
1. Ввести в КоАП РФ и КоАП РК институт соучастия, когда к ответственности наряду с исполнителем привлекаются организатор и пособник правонарушения, как это прямо предусмотрено в КоАП РБ.

2. Ввести в КоАП РФ и КоАП РК институт покушения на совершение АП в случаях, как это прямо предусмотрено в КоАП РБ.

3. Установить едиными сроки давности привлечения к административной ответственности за нарушение таможенных правил в кодексах об административной ответственности государств членов Таможенного союза.
4. Ввести институт приостановления течения срока давности привлечения к административной ответственности, как это прямо предусмотрено в КоАП РК.

5. Ввести институт соединения в КоАП РФ, как это прямо предусмотрено в КоАП РК и КоАП РБ).

6. Договор об особенностях уголовной и административной ответственности за нарушения таможенного законодательства Таможенного союза и государств - членов Таможенного союза. Решение Межгоссовета ЕврАзЭС от 05.07.2010 № 50.

\section{Библиография:}

1. Кодекс об административных правонарушениях Республики Казахстан: Закон Республики Казахстан от 30.01.2001 № 156-II [Электронный pecypc].URL: http://www.zakon.kz/static/administrativnyykodex.html / (дата обращения: 24.02.2014).

2. Процессуально-исполнительный кодекс Республики Беларусь: Закон Республики Беларусь от 20.12.2006 № 1943 [Электронный ресурс]. URL: http://tamby.info/kodeks/pikoap.htm /дата обращения: 24.02.2014).

3. Кодекс об административных правонарушениях Республики Беларусь: Закон Республики Беларусь от 21.04.2003 № 194-3 [Электронный ресурc]. URL: http://tamby.info/kodeks/pikoap.htm / (дата обращения: 24.02.2014).

4. Кодекс Российской Федерации об административных правонарушениях. (в ред. от 15.02.2014 № 6-Ф3) // Собрание законодательства РФ.2002, № 1 (ч. 1). Ст. 1.

5. Таможенный кодекс Таможенного союза (приложение к Договору о Таможенном кодексе Таможенного союза, принятому Решением Межгосударственного совета ЕврАзЭС на уровне глав государств от 27.11.2009 № 17) (в ред. от 16.04.2010) // Собрание законодательства РФ.2010. № 50. Ст. 6615.

6. Договор об особенностяхуголовной и административной ответственности за нарушения таможенногозаконодательства Таможенного союза и государств - членов Таможенного союза. Решение Межгоссовета ЕврАзЭС от 05.07.2010 № 50. 8. Стригунова Н.Ю. Доказывание по делам об административных правонарушениях в области таможенного дела в государствах-членах Таможенного союза ЕврАзЭС (сравнительно-правовой анализ) // Административное и муниципальное право.-2013.-10.-C. 980-985. DOI: 10.7256/1999-2807.2013.10.9765. 9. Мошкина Н.А. Реализация интересов государств в условиях интеграции (на примере таможенного союза России, Белоруссии и Казахстана) // NB: Международные отношения.-2012.-1.-C. 80-91. URL: http://www.e-notabene.ru/wi/article_32.html

\section{References (transliterated):}

1. Kodeks ob administrativnykh pravonarusheniyakh Respubliki Kazakhstan: Zakon Respubliki Kazakhstan ot 30.01.2001 № 156-II [Elektronnyi resurs].URL: http://www.zakon.kz/static/administrativnyykodex.html / (data obrashcheniya: 24.02.2014).

2. Protsessual'no-ispolnitel'nyi kodeks Respubliki Belarus': Zakon Respubliki Belarus' ot 20.12.2006 № 194-Z [Elektronnyi resurs]. URL: http://tamby.info/kodeks/pikoap.htm /data obrashcheniya: 24.02.2014).

3. Kodeks ob administrativnykh pravonarusheniyakh Respubliki Belarus': Zakon Respubliki Belarus' ot 21.04.2003 № 194Z [Elektronnyi resurs]. URL: http://tamby.info/kodeks/pikoap.htm / (data obrashcheniya: 24.02.2014).

4. Kodeks Rossiiskoi Federatsii ob administrativnykh pravonarusheniyakh. (v red. ot 15.02.2014 № 6-FZ) // Sobranie zakonodatel'stva RF.2002, № 1 (ch. 1). St. 1.

5. Tamozhennyi kodeks Tamozhennogo soyuza (prilozhenie k Dogovoru o Tamozhennom kodekse Tamozhennogo soyuza, prinyatomu Resheniem Mezhgosudarstvennogo soveta EvrAzES na urovne glav gosudarstv ot 27.11.2009 № 17) (v red. ot 16.04.2010) // Cobranie zakonodatel'stva RF.2010. № 50. St. 6615.

6. Dogovor ob osobennostyakh ugolovnoi i administrativnoi otvetstvennosti za narusheniya tamozhennogo zakonodatel'stva Tamozhennogo soyuza i gosudarstv - chlenov Tamozhennogo soyuza. Reshenie Mezhgossoveta EvrAzES ot 05.07.2010 № 50. 8. Strigunova N.Yu. Dokazyvanie po delam ob administrativnykh pravonarusheniyakh v oblasti tamozhennogo dela v gosudarstvakh-chlenakh Tamozhennogo soyuza EvrAzES (sravnitel'no-pravovoi analiz) // Administrativnoe i munitsipal'noe pravo.-2013.-10.-C. 980-985. DOI: 10.7256/1999-2807.2013.10.9765. 9. Moshkina N.A. Realizatsiya interesov gosudarstv v usloviyakh integratsii (na primere tamozhennogo soyuza Rossii, Belorussii i Kazakhstana) // NB: Mezhdunarodnye otnosheniya.-2012.-1.-C. 80-91. URL: http://www.e-notabene.ru/wi/article_32.html 